\title{
Tree Ring and Climate change in Langtang National Park, Central Nepal
}

\author{
P.K. Chhetri*1 ${ }^{1}$ and S. Thapa ${ }^{2}$ \\ ${ }^{1}$ Graduate School of Environmental Science, Hokkaido University, Sapporo, Hokkaido, Japan \\ ${ }^{2}$ Global Land Project, Sapporo Nodal Office, Hokkaido University, Sapporo, Hokkaido, Japan \\ *E-mail: parveenchhetri@gmail.com
}

Received: 25.02.2010, Accepted: 29.09.2010

\begin{abstract}
In present study 120 tree cores from 60 trees of Abies spectabilis from two different sites Chandanbari and Cholangpati area of Langtang National Park were collected. Analysis of increment cores showed that trees in those stands were 100-300 years old. Trees of Chandanbari site were found to be older than Cholangpati. Mean tree ring width of Chandanbari was $2.34 \mathrm{~mm}$ and that of Cholangpati site $1.70 \mathrm{~mm}$. Growth rate was higher $(2.34 \mathrm{~mm} / \mathrm{yr})$ at the Chandanbari than that of Cholangpati $(1.70 \mathrm{~mm} / \mathrm{yr})$. Series intercorrelation and mean sensitivity were 0.457 and 0.223 for Chandanbari and 0.499 and 0.203 for Cholangpati, respectively. The high mean sensitivity value indicated that high inter-annual variability was present in the ring widths and that the chronology was sensitive to yearly environmental changes; ring width was negatively correlated with minimum monthly temperature and positively correlated with total monthly precipitation.
\end{abstract}

Key words: Climate change, tree ring, dendrochronology, Abies spectabilis

\section{Introduction}

Analysis of observed temperature and precipitation records in Nepal shows that temperature in Nepal is increasing at a high rate in comparison to other mountains of the world (Shrestha et al., 1999). The warming seems to be consistent and continuous after the mid-1970s and found to be more pronounced at high altitude. Therefore, the studies of climate change are urgently needed in order to better understanding the linkage between changing climatic pattern, increasing natural hazards and its effects on livelihood. But the climatic records in Nepal are very limited. Most of the meteorological stations are located at lower elevation $(<2000 \mathrm{~m})$, therefore time series analysis of recorded climate data for the assessment of climate change at higher altitude is not possible. We need to identify alternative way to study climate. One of such alternative could be dendrochronology, and dendroclimatology.

Since Nepal's altitude ranges between 60-8848 $\mathrm{m}$ we find different climate from tropical to tundra. As a result, different potential tree species are available which could be used in dendroclimatic studies. The pines and firs are the most dominant species at higher altitudes of Nepal, which we can be used to reconstruct the past climate. In this context present study was carried to investigate the growth pattern of tree ring and develop tree ring chronology of $A$. spectabilis and to compare response of $A$. 
spectabilis ring width with climate (temperature and precipitation).

\section{Methodology}

This study was carried out in Chandanbari $\left(28^{\circ} 07^{\prime} 27.9^{\prime \prime} \mathrm{N}, \quad 85^{\circ} 21^{\prime} 12.3^{\prime \prime} \mathrm{E}\right) \quad$ and Cholangpati $\left(28^{\circ} 06^{\prime} 20.5^{\prime \prime} \mathrm{N}, 85^{\circ} 21^{\prime} 44.7^{\prime \prime} \mathrm{E}\right)$ of Langtang National Park in June 2007. Single stand A. spectabilis forest of Chandanbari and Cholangpati was selected for tree ring sampling. Chandanbari and Cholangpati were designated as site I and II respectively (Tab. 1, Fig. 1).

Table 1. Description of the sampling site.

\begin{tabular}{lll}
\hline Description & Site I & Site II \\
\hline Altitude $(\mathrm{m})$ & 3309 & 3444 \\
Slope $\left(^{\circ}\right)$ & 35 & 30 \\
Slope direction & $\mathrm{NE}$ & $\mathrm{NE}$ \\
Average DBH $(\mathrm{cm})$ & 76.49 & 85.75 \\
Average height $(\mathrm{m})$ & 35.29 & 36.34 \\
Soil depth (m) & $1-1.5$ & $1-1.5$ \\
\hline
\end{tabular}

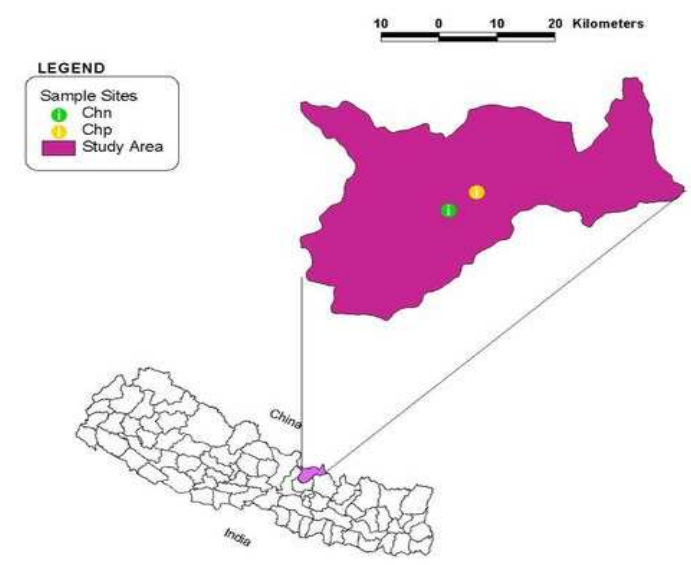

Figure 1. Map showing Cholangpati (Chp) and Chandanbari (Chn).

Silver fir (Abies sp.) is a species commonly researched in dendrochronology, due to its sensitivity to disturbance factors. A. spectabilis is the most studied species from Nepal so it was selected for the study.
Trees with major defects (i.e., multiple stems, heavy insect damage, or severe scarring) were not sampled.

To obtain a mean tree ring chronology, 10-30 trees were used. For ring width analysis a sample of two cores from each 20 trees was taken (Cook and Kairiukstis, 1990). For present study, 60 trees were cored and two samples from each tree were collected from two different sites Chandanbari (Site I) and Cholangpati (Site II) in Langtang National Park. A total of 30 trees were cored from each site.

Sample from selected tree was taken with the help of increment borer. Sample was taken at breast height. The two increment cores from each tree were taken at $90^{\circ}$ to $180^{\circ}$ from each other and as far as possible parallel to the topographic contour.

Cores were air dried for 10 days and then placed in grooved wooden mounts with the trachieds aligned vertically to give cross-sectional surface. To make the core surface smooth, the specimens were polished using a rotary electric belt sander with progressively finer grades of sand paper (60- to 320- grit).

Sliding-stage micrometer of Tree Ring and Climate Change Lab, FERS, Mahidol University, Bangkok, Thailand was used for tree ring width measurement and other lab analysis. Tree-ring series were crossdated on the light table to find similarities in the growth pattern. After measurement of ring width, tree rings were analyzed with the help of software's COFECHA (Holmes, 1983) and ARSTAN (Cook and Holmes, 1986).

Response-function analysis (program Dendro Clim 2002; Biondi and Waikul, 2004) was carried out to assess the impact of changes in monthly mean temperature and the precipitation. Since long term 
meteorological records at high altitude near sampling site were not sufficient, so we selected the metrological data (temperature 1971-2005 and precipitation 1971-2005) of Kathmandu airport $\left(27^{\circ} 42^{\prime} \mathrm{N}, 85^{\circ} 18^{\prime} \mathrm{E} ; 1336\right.$ $\mathrm{m})$, located about $50 \mathrm{~km}$ from sampling site. Precipitation data (1971-2005) of Dhunche $\left(28^{\circ} 06^{\prime} \mathrm{N}, 85^{\circ} 18^{\prime} \mathrm{E} ; 1982 \mathrm{~m}\right)$ was also used for response analysis.

\section{Results and discussion}

The main dendrochronological parameters such as average ring width, standard deviation and mean sensitivity were calculated, and autocorrelation and crossdating coefficients were defined for the mean chronologies. Statistical characters of both sites are given in table 2 .

Table 2. Statistical characteristics of A. spectabilis chronologies.

\begin{tabular}{|c|c|c|}
\hline Characteristics & Site I & Site II \\
\hline Total trees cored & 30 & 30 \\
\hline No of cores & 60 & 60 \\
\hline Number of dated series & 38 & 26 \\
\hline Master series & $\begin{array}{l}1776-2006 \\
(231 \mathrm{yrs})\end{array}$ & $\begin{array}{l}1881-2006 \\
(186 \text { yrs })\end{array}$ \\
\hline Mean measurement & 2.340 & 1.700 \\
\hline Series intercorelation & 0.457 & 0.499 \\
\hline $\begin{array}{l}\text { Average mean } \\
\text { sensitivity }\end{array}$ & 0.223 & 0.203 \\
\hline Autocorrelation & 0.828 & 0.839 \\
\hline Std. deviation & 1.390 & 0.960 \\
\hline $\begin{array}{l}\text { Mean correlation within } \\
\text { trees }\end{array}$ & 0.276 & 0.238 \\
\hline Signal to noise ratio & 14.106 & 7.183 \\
\hline $\begin{array}{l}\text { Expressed population } \\
\text { signal }\end{array}$ & 0.934 & 0.878 \\
\hline
\end{tabular}

The mean sensitivity ranged from 0.203 to 0.223 indicating that high interannual variability was present in the ring widths and that the chronology was sensitive to yearly environmental changes. Mean sensitivity around 0.2 is generally accepted as series that are sensitive enough for climate reconstruction. The autocorrelation value that is higher than 0.5 indicates high autocorrelation or tree-ring width of the previous year influencing tree ring width of the present year. The autocorrelation value of this study ranged from 0.828 to 0.839 . The Expressed Population Signal (EPS) is a measure of the common variability in a chronology which is dependent upon sample depth. EPS value of Site I Chronology was 0.934 and Site II was 0.878 . A value of 0.85 has frequently been used as an appropriate cut-off point and benchmark of signal strength of a chronology (Cook and Kairiukstis, 1990).

Residual site chronologies "site chronologies" were developed for the years 1778-2006 for Site I and 1881-2006 for Site II and master chronology by combining both sites by using ARSTAN program (Cook and Holmes, 1986). Master chronology and individual chronology of $A$. spectabilis is presented in figure 2 . This 250 years tree ring width chronology is comparatively short in comparison to other studies form Nepal (Khanal and Rijal, 2002; Cook et al., 2003). The length of tree ring chronologies was limited by butt rot in most of the oldest trees. Similar, problem was faced by Sano et al. (2005) in their study in western Nepal.

The DENDROCLIM 2002 (Biondi and Waikul, 2004) software was applied for the analysis, using bootstrapped confidence intervals to estimate the significance of both correlation and response function coefficients and testing their significance at the 0.05 level. The total monthly precipitation and mean, maximum, minimum monthly temperature of the previous year and of the current year were used as predictor variables to determine the significance of their effects on concurrent 


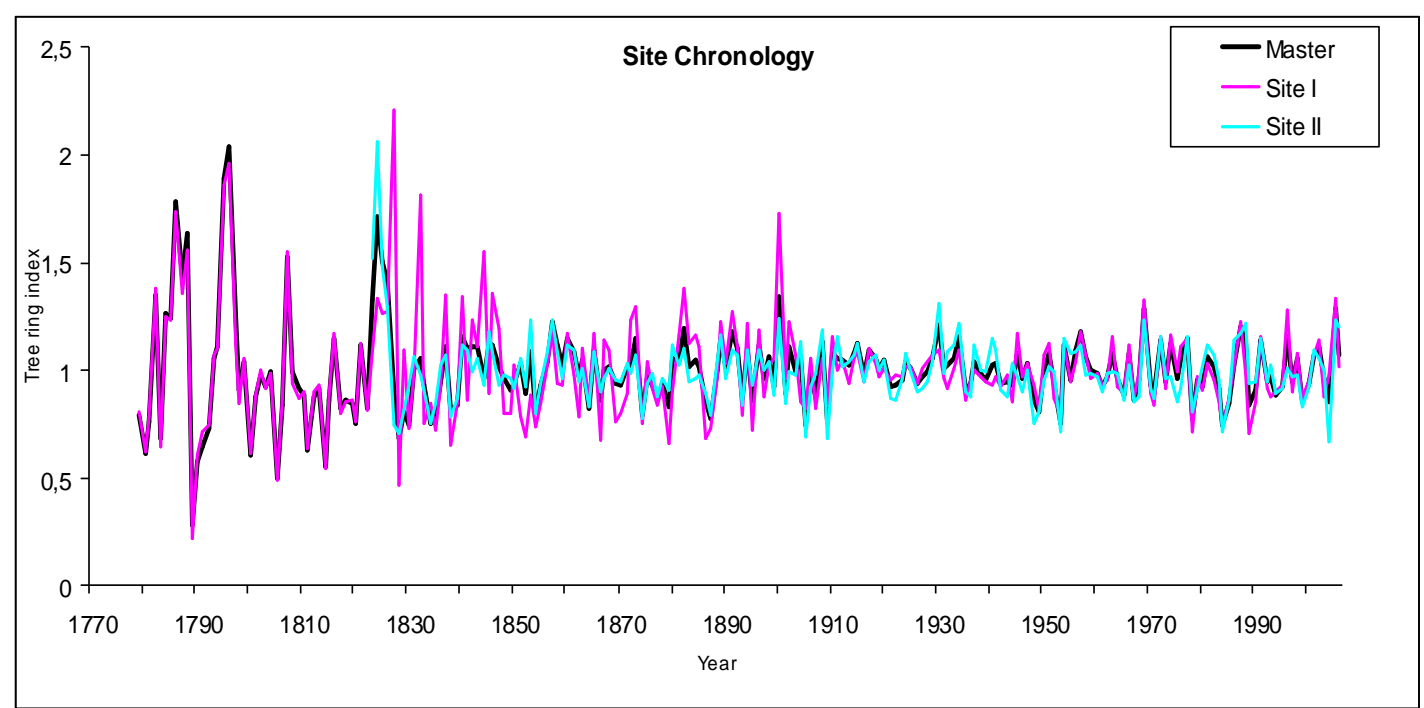

Figure 2. Master and individual site chronologies of A. spectabilis.

ring growth. Tree growth of the Himalayan region is primarily limited by the moisture availability in pre-monsoon season (MarchMay), with a negative association with temperature and a positive association precipitation (Borganokar et al., 1999). We found that tree ring parameter of Site II, positively correlated with March total precipitation and negatively correlate with monthly minimum temperature of May. This result indicated that ring width was primarily controlled by the pre monsoon temperature and precipitation. Similar result was found in response analysis of tree-ring parameters of A. spectabilis with climate records from Western Nepal (Sano et al., 2005) and Central Nepal (Khanal and Rijal, 2002).

These values of chronology statistics and result of response analysis showed that A. spectabilis chronology of Chandanbari and Cholangpati can be used for climatic reconstruction. But one of the major difficulties in dendroclimatic reconstruction of past climate in Nepal is the paucity of long term meteorological records for statistically calibrating tree rings (Bhattacharayya et al., 1992; Cook et al., 2003; Sano et al., 2005). In this study also available climatic data and sample size was not so enough for past climate reconstruction.

\section{Conclusions}

A major international effort is underway to reconstruct past climate at high-elevation sites to address uncertainties in predicting physical and biological responses to climate change at decadal timescales at higher elevation environments (Beniston, 1994). In this study, we tried to explore the potential of tree-ring records from the high elevation Abies forest of Nepal for identifying major patterns of climatic variability. The results of present study showed that A. spectabilis trees of Chandanbari and Cholangpati area 
can be used in dendroclimatological study and construction of past climate.

\section{Acknowledgements}

Thanks are due to Prof. N.R. Khanal, Tribhuvan University; Prof. N. Pumijumong, Mahidol University; Ass. Prof. T. Watanabe, Hokkaido University; Dr. D. Regmi; WWF Nepal-small grant program and DNPWC for their generous help and suggestions.

\section{References}

Beniston, M. 1994. Mountain environments in changing climates. Routledge, London and New Yourk. 492 p.

Bhattacharyya, A., V.C. LaMarche Jr. and M.K. Hughes 1992. Tree-ring chronologies from Nepal. Tree-Ring Bull. 52: 59-66.

Biondi, F. and K. Waikul 2004. Dendroclim 2002: $\mathrm{AC}++$ program for statistical calibration of climate signals in tree ring chronology. Comp. Geosci. 30: 303-311.

Borganokar, H.P., G.B. Pant and K. Rupa Kumar 1999. Tree-ring chronologies from western Himalaya and their dendroclimatic potential. IAWA Journal 20: 259-309.

Cook, E.R. and L.A. Kairiukstis 1990. Methods of dendrochronology: applications in environme- ntal science. Kluwer, Dotrecht. pp. 104-123.

Cook, E.R. and R.L. Holmes 1986. User manual for program Arstan. In Tree-ring chronologies of western North America, California, eastern Oregon and northen Great Basin (Eds. R.L. Holmes, R.K. Adams and H.C. Fritts) Chronology series IV. University of Arizona.

Cook, E.R., P.J. Krusic and P.D. Jones 2003. Dendroclimatic signals in long tree-ring chronologies from the Himalayas of Nepal. Intern. J. Climatol. 23: 707-732.

Holmes, R.L. 1983. Computer-assisted quality control in tree-ring dating and measurement. TreeRing Bull. 43: 69-78.

Khanal, N.R. and S.P. Rijal 2002. Tree ring chronology from Ganesh Himal area, Central Nepal. In Geothermal/dendrochronological paleoclimate reconstruction across eastern margin of Eurasia. Proceeding 2002 International Mastsuyama Workshop. pp. 1219.

Sano, M., F. Furuta, O. Kobayashi and T. Sweda 2005. Temperature variations since the mid$18^{\text {th }}$ century for western Nepal, as reconstructed from tree-ring width and density of Abies spectabilis. Dendrochronologia 23: 83-92.

Shrestha, A.B., C.P. Wake, P.A. Mayewski and J.E. Dibb 1999. Maximum temperature trends in the Himalaya and its vicinity: An analysis based on temperature records from Nepal for the period 1971-94. J. Climate 12: 2775-2789. 